\title{
An Empirical Study on Influence of Flipped Classroom on College English Listening and Speaking Classroom Environment
}

\author{
Qinghua Fang and Jiabei Jiang \\ Wuhan University of Science and Technology, Wuhan, Hubei, China \\ 312852383@qq.com,372967140@qq.com
}

\begin{abstract}
Keywords: Classroom environment; Flipped classroom; College English Listening and Speaking; Influence difference
\end{abstract}

\begin{abstract}
The study investigates influence of flipped classroom pedagogy on College English Listening and Speaking classroom environment, focusing on class difference as well as individual difference in students' perception of CELS classroom environment. Quantitative and qualitative analyses show that flipped classroom pedagogy has exerted more positive influence on CELS classroom environment for the top 10 classes while more negative influence for the bottom 10 classes. Students of different language proficiencies have different perceptions of the flipped College English of Listening and Speaking classroom environment. The higher students' English proficiencies are, the better perception of the flipped classroom environment they have. However, for students whose scores are in the low level interval (0-69), the influence is negatively obvious between the flipped classroom and the non-flipped classroom. The negative differences are more significant for those students whose scores are under 60.
\end{abstract}

\section{Research Background}

With the further reforms in higher education, class hours of College English Listening and Speaking (shorted for CELS) have decreased significantly, which makes the formerly-existing problems such as limited time for practicing oral English in class, students' inadequate accumulation of pre-class language in-put, students' inadequate language out-put in class, insufficient class interactions between students, and inefficient class interactions between teacher and students, etc. become more serious. Correspondingly, the classroom environment is far from what we expect.

Since the rise of flipped classroom in America in 2011, it has been applied into the practical teaching more and more. This new teaching pedagogy overturns the traditional teaching mode "teacher's teaching+students' homework" into "self-learning before class+collaboration \& exploration in classroom" [1]. It flips both teacher's and students' roles and provides a new insight into improving the learning efficiency. Many researchers conducted studies concerning the comparison between traditional classroom and flipped classroom. Lage and Platt found that flipped classroom exerted obvious effect in improving the flexibility of learning, training communication ability and cultivating high-level thinking ability [2]. By comparing flipped classroom with traditional classroom, Jeremy F. Strayer [3] confirmed that flipped classroom had significant effect on students' cooperation ability and innovation ability and was effective means to help fostering learners' collaboration and innovation.

At home, researches of flipped classroom were also being carried out in a lively way. Ma, Zhao and Wu's empirical study [4] showed that flipped classroom could promote the learner's cooperation ability, innovation ability and autonomous learning ability based on College Information Technology class. From the perspective of learning environment and situations, flipped classroom was conducive to students' cooperative or collaborative learning, to promote the interaction between students and between students and teachers, to explore knowledge and to complete acquisition [5]. In recent years, the number of studies on influence of flipped classroom on college student's ability development was rising. There was a close relationship between students learning adaptability that FCM cultivated and learning ability such as learning independence, teamwork ability, knowledge integration, knowledge migration ability, attention, 
mental quality, learning achievement and learning self-confidence [6].

Flipped classroom teaching pioneers also show that the localization of flipping teaching can really bring positive effects to the development of students through the theoretical and practical researches [7]. For example, flipped classroom produces greater student engagement and deeper learning; it permits students to learn English at their own pace, which brings about more of the students', esp. poor students' collaboration and participation. In addition, flipped classroom enables teachers to make good use of classroom time to personalize their own teachings. All these bring hope to solve some difficulties in College English teaching in China. Therefore, it is of significance to explore and construct a College English Listening and Speaking flipped classroom model to investigate the influence the model exerts on learners' classroom environment.

\section{Theoretical Foundation}

Classroom environment refers to the social psychological environment of classroom, which is the aggregation of teacher-student interaction and student-student interaction on the basic elements and conditions as well as classroom participants' personality, mental state and the psychological atmosphere of the classroom [8]. This study sets out from the perspective of classroom social environment and psychological environment to define classroom environment, with reference to Sun's study of sociopsychological environment in the foreign language classroom[9], consisting of factors such as "Student's Collaboration", "Student's Cooperation", "Teacher's Support", "Teacher's Leading", "Classroom Involvement", "Student's Responsibility", "Task Orientation", "Equality" and "Teacher's Innovation". From the perspective of students' perception to measure the specific factors that influence the classroom environment is more reliable than the intuitive observation and more systematic for the scientific study.

\section{Flipped Classroom of Listening and Speaking}

In view of the traits and advantages of flipped classroom, along with the characteristics of CELS, the specific teaching model of flipped classroom based on the researches of the pioneers has been designed. Flipped classroom relies on using modern technology effectively to help students conduct meaningful and discovery learning. At first, internet platforms are established, including teaching forum, chatting groups (QQ or We-chat), network community, and so on, to facilitate the interaction between teacher and students. Before class the teacher subdivides teaching contents into a plurality of knowledge chunks, record the important and difficult points into micro videos, the length of which is about 5 minutes. Before class, the students can either choose to complete the tasks independently or in cooperation with other partners. After completing online learning, students not only need to complete the online homework, but also the self-testing to check their mastery of the contents. In class, the teacher checks whether the contents have been mastered ahead of schedule by distributing assignments such as word blank-filling, reports, summary for students to consolidate what they have learned, to enable them to enhance their listening as well as speaking abilities. The classroom activities are conducted in the form of individual work, team-work, asking and answering questions, etc. Students' performances are included as 50\% of their final grades.

\section{Research Methodology}

Research Questions. To identify the influence of flipped classroom model on classroom environment of CELS, the study tries to answer three questions:

1. Does flipped classroom exert influence on the classroom environment of CELS?

2. Is there any class difference in perception of CELS classroom environment between top10 classes (with flipped classroom and non-flipped classroom respectively) and bottom 10 classes (with flipped classroom and non-flipped classroom respectively)?

3. Is there any proficiency difference in perception of CELS classroom environment between students in flipped classroom classes and students in non-flipped classroom classes? 
Research Subjects. In this study, the subjects are undergraduate non-English majors of 2014 Grade in Wuhan University of Science and Technology. Altogether there are 40 different classes. Based on the average class scores of the second term's final English test of Listening and Speaking, these 40 classes in are selected, top10 classes in flipped classroom; top10 classes in non-flipped classroom; bottom10 classes in flipped classroom, and bottom10 classes are in the non-flipped classroom. In designing the questionnaire, students are classified according to their different proficiency levels of listening and speaking. There are five different groups of students whose scores are in the range of $0-59,60-69,70-79,80-89,90-100$. Such classification of the subjects is made in order to investigate whether there is difference in students' perception of flipped classroom environment between students of different proficiency levels.

Research Instruments. Two instruments are used to obtain data for the study, including "College English of Listening and Speaking Classroom Environment Inventory" (CERWTCEI) and an interview.

Questionnaire. The questionnaire used in the study is designed on the basis of Sun Yunmei's College English Class Inventory (CCECEI) and Fraser's WIHIC (What is Happening In the class) and takes into account the characteristics of English Listening and Speaking class. The two questionnaires are proved to have high reliability and validity as they have been used in various classroom environments. More importantly; the CCECEI is designed for the Chinese College English classroom environment. Therefore, the reliability, validity and suitability of CERWTCEI can be guaranteed theoretically. Given that this paper focuses on the influence of flipped classroom on college students' perception of the environment of College English Listening and Speaking, the author also consulted some experienced teachers and got some valuable suggestions so as to improve the questionnaire.

Interview. At the end of the experiment, interviews are conducted investigate students as to their views about the flipped classroom. Some main questions are as follows:

1. How do you think about the new teaching mode conducted in this semester?

2. Do you think your learning efficiency has been improved? Why?

3. Are you more willing to participate in classroom activities? Why?

4. Do you hope to keep the flipped classroom mode for the rest semesters?

Research Procedure. At the beginning of the second semester in sophomore, questionnaires are distributed to students to get the pretest data. During the experiment process, the teacher keeps interviewing students. At the end of the semester, the teacher distributes questionnaires again to collect post-test data. All data are analyzed by SPSS 20. Information from interview is used for supplementary evidence.

\section{Data Analysis and Discussion}

\section{General Situation of Flipped Classroom's Influence on CELS}

Table 1 Independent Sample Test of Difference between FN and NFC

\begin{tabular}{|c|c|c|c|c|c|c|c|}
\hline Factors & $\begin{array}{l}\text { Flipped/Non- } \\
\text { flipped classroom }\end{array}$ & $\mathrm{t}$ & df & $\begin{array}{c}\text { Sig. } \\
\text { (2-tailed) }\end{array}$ & Mean & $\begin{array}{c}\text { Mean } \\
\text { Difference }\end{array}$ & $\begin{array}{l}\text { Std. Error } \\
\text { Difference }\end{array}$ \\
\hline \multirow{2}{*}{$\begin{array}{c}\text { Student's } \\
\text { Cooperation }\end{array}$} & Flipped & 3.904 & 1215 & .000 & 3.9502 & .13915 & .03565 \\
\hline & Non-Flipped & 3.904 & 1214.564 & .000 & 3.9715 & .13915 & .03565 \\
\hline \multirow{2}{*}{$\begin{array}{c}\text { Task } \\
\text { Orientation }\end{array}$} & Flipped & -3.152 & 1215 & .002 & 3.6671 & -.11435 & .03628 \\
\hline & Non-Flipped & -3.152 & 1203.755 & .002 & 3.7815 & -.11435 & .03628 \\
\hline \multirow{2}{*}{$\begin{array}{c}\text { Student's } \\
\text { Responsibility }\end{array}$} & Flipped & 3.904 & 1215 & .000 & 3.9964 & .13915 & .03565 \\
\hline & Non-Flipped & 3.904 & 1214.564 & .000 & 3.8572 & .13915 & .03565 \\
\hline \multirow{2}{*}{ Equality } & Flipped & -3.152 & 1215 & .002 & 3.6671 & -.11435 & .03628 \\
\hline & Non-Flipped & -3.152 & 1203.755 & .002 & 3.7815 & -.11435 & .03628 \\
\hline \multirow{2}{*}{$\begin{array}{l}\text { Teacher's } \\
\text { Innovation }\end{array}$} & Flipped & 2.654 & 1215 & .008 & 4.0279 & .10390 & .03915 \\
\hline & Non-Flipped & 2.654 & 1215.00 & .008 & 3.9240 & .10390 & .03915 \\
\hline
\end{tabular}

The following will analyze statistics got from the questionnaire, and will mainly discuss and solve the problems put forward previously. For convenience, we use some abbreviations for the 
readers. "FC" is shortened for "Flipped Classroom", "NFC" for "Non-Flipped Classroom" and "CELS" for "College English Listening and Speaking".

From Table 1, we can see the means of Student's Cooperation, Student's Responsibility and Teacher's Innovation in the flipped classroom are obviously higher than the corresponding means in the non-flipped classroom. It can be shown that flipped classroom exerts some positive influence on the classroom environment of CELS. Surprisingly, the means of classroom environment factors such as Task Orientation, and Equality in the flipped classroom are lower than those in the non-flipped classroom. Independent sample test of these 5 factors between the flipped classroom and non-flipped classroom also shows that there is significant difference in the 5 classroom environment factors mentioned above because all their $\mathrm{P}$ values are less than 0.05 . This again proves that flipped classroom exerts some influence on the classroom environment of CELS. For Student's Cooperation, Student's Responsibility and Teacher's Innovation, the influence is positive; for Task Orientation and Equality, the influence is negative.

\section{Class Difference between FC Top10 Classes and NFC Top10 classes}

Table 2 Group Statistics of FC Top10 Classes and NFC Top10 Classes

\begin{tabular}{|c|c|c|c|c|c|c|c|}
\hline Factors & $\begin{array}{l}\text { Flipped/Non-flip } \\
\text { ped classroom }\end{array}$ & $\mathrm{t}$ & df & $\begin{array}{l}\text { Sig. } \\
\text { (2-taile } \\
\text { d) }\end{array}$ & Mean & $\begin{array}{c}\text { Mean } \\
\text { Difference }\end{array}$ & $\begin{array}{l}\text { Std. Error } \\
\text { Difference }\end{array}$ \\
\hline \multirow{2}{*}{$\begin{array}{c}\text { Student's } \\
\text { Collaboration }\end{array}$} & Flipped & 3.055 & 628 & .002 & 4.0073 & .13025 & .04264 \\
\hline & Non-Flipped & 3.056 & 627.734 & .002 & 3.8770 & .13025 & .04263 \\
\hline \multirow{2}{*}{$\begin{array}{c}\text { Student's } \\
\text { Cooperation }\end{array}$} & Flipped & 5.009 & 628 & .000 & 4.0511 & .24850 & .04961 \\
\hline & Non-Flipped & 5.007 & 625.440 & .000 & 3.8026 & .24850 & .04963 \\
\hline \multirow{2}{*}{$\begin{array}{c}\text { Classroom } \\
\text { Involvement }\end{array}$} & Flipped & 3.316 & 628 & .001 & 3.5644 & .13371 & .04032 \\
\hline & Non-Flipped & 3.319 & 628.000 & .001 & 3.4307 & .13371 & .04029 \\
\hline \multirow{2}{*}{$\begin{array}{c}\text { Student's } \\
\text { Responsibility }\end{array}$} & Flipped & 5.009 & 628 & .000 & 4.0511 & .24850 & .04961 \\
\hline & Non-Flipped & 5.007 & 625.440 & .000 & 3.8026 & .24850 & .04963 \\
\hline \multirow{2}{*}{$\begin{array}{l}\text { Teacher's } \\
\text { Innovation }\end{array}$} & Flipped & 2.390 & 628 & .017 & 4.0249 & .13366 & .05591 \\
\hline & Non-Flipped & 2.391 & 627.353 & .017 & 3.8913 & .13366 & .05591 \\
\hline
\end{tabular}

From Table 2 we can see the mean values for Student's Collaboration, Student's Cooperation, Classroom Involvement, Student's Responsibility, and Teacher's Innovation in the flipped classroom of top 10 classes are higher than those of the non-flipped top 10 classes' classroom. It can be found that flipped classroom can help to improve the top10 classes' CELS classroom environment, especially when it comes to factors like Student's Cooperation and Student's Responsibility. Independent Sample Test also helps to verify the above finding: the P values of Student's Collaboration, Student's Cooperation, Classroom Involvement, Student's Responsibility, and Teacher's Innovation are all lower than 0.05, which shows that there exists significant difference in these 5 factors between the flipped classroom top 10 classes and non-flipped classroom top10 classes.

\section{Class Difference between FC Bottom10 Classes and NFC Bottom10 Classes}

Table 3 Group Statistics of FC Bottom10 Classes and NFC Bottom10 Classes

\begin{tabular}{|c|c|c|c|c|c|c|c|}
\hline Factors & $\begin{array}{l}\text { Flipped/Non-flippe } \\
\text { d classroom }\end{array}$ & $\mathrm{t}$ & $\mathrm{df}$ & $\begin{array}{c}\text { Sig. } \\
\text { (2-tailed } \\
\text { ) }\end{array}$ & Mean & $\begin{array}{c}\text { Mean } \\
\text { Difference }\end{array}$ & $\begin{array}{l}\text { Std. Error } \\
\text { Difference }\end{array}$ \\
\hline \multirow{2}{*}{$\begin{array}{c}\text { Student' s } \\
\text { Collaboration }\end{array}$} & Flipped & -3.920 & 585 & .000 & 3.8866 & -.18255 & .04657 \\
\hline & Non-Flipped & -3.914 & 577.065 & .000 & 4.0691 & -.18255 & .04664 \\
\hline \multirow{2}{*}{$\begin{array}{c}\text { Task } \\
\text { Orientation }\end{array}$} & Flipped & -4.900 & 585 & .000 & 3.5437 & -.26094 & .05326 \\
\hline & Non-Flipped & -4.891 & 574.357 & .000 & 3.8046 & -.26094 & .05336 \\
\hline \multirow[t]{2}{*}{ Equality } & Flipped & -4.900 & 585 & .000 & 3.5437 & -.26094 & .05326 \\
\hline & Non-Flipped & -4.891 & 574.357 & .000 & 3.8046 & -.26094 & .05336 \\
\hline
\end{tabular}


From Table 3 we can see the difference values in means for environment factors between flipped classroom bottom 10 classes and non-flipped classroom bottom 10 classes are not as evident as those between top10 classes. It is beyond our expectation that some factors' mean difference is negative, which can be seen from mean difference for Student's Collaboration, Task Orientation and Equality. For those factors whose mean difference is positive, the difference is very slight. And all obvious differences are found negative, which shows flipped classroom has more negative influence on these factors of the classroom environment in the bottom 10 classes. Thus it can be seen that environment in the flipped classroom bottom 10 classes is even worse than that of the non-flipped classroom bottom 10 classes. At least we can anticipate that some students in bottom 10 classes may behave worse in the flipped classroom. Independent Sample Test tells that the P values of Student's Collaboration, Task Orientation, and Equality are all lower than 0.05, which shows the negative differences are significant in these factors between the flipped classroom bottom 10 classes and non-flipped classroom bottom 10 classes. It again proves that the flipped classroom has negative influence on the classroom environment of bottom 10 classes concerning these 3 factors.

\section{Summary.}

The above analyses show that flipped classroom has exerted some influence on the classroom environment of CELS. Between the top10 classes and bottom 10 classes, the influence on some classroom environment factors is different. Some influence is even on the opposite side.

Influence of flipped classroom on classroom environment of the top10 classes is significant. Obviously, students in these classes collaborate and cooperate better with each other. They involve themselves more in classroom activities and have higher sense of responsibility for their own English learning. Also they have more appreciation of their teachers' innovative teaching. In class, these students have more confidence in themselves and feel better about their performance, which correspondingly raise their interest in learning English and take active part in classroom activities.

However, flipped classroom has exerted more negative influence on classroom environment of the bottom10 classes. Students in these classes collaborate worse than their counterparts in the top10 classes. It is more difficult for them to finish their assignments. In the flipped classroom, more practice activities mean more challenges for them because they are not well-prepared, which will make them feel under more pressure. More of them don't have so much confidence in themselves and will not try to seize opportunities to interact with other classmates or with the teacher. Undoubtedly, the classroom environment is affected negatively.

\section{Proficiency Difference in Perception of CELS Classroom Environment between Students in FC and Students in NFC}

Table 4 Group Statistics for Students of Different Groups in the FC and NFC

\begin{tabular}{|c|l|c|c|c|c|c|c|c|c|c|}
\hline $\begin{array}{l}\text { Score } \\
\text { Section }\end{array}$ & $\begin{array}{l}\text { Flipped/Non-Flippe } \\
\text { d classroom }\end{array}$ & 1 & 2 & 3 & 4 & 5 & 6 & 7 & 8 & 9 \\
\hline $0-59$ & Flipped & 3.57 & 3.02 & 3.52 & 3.79 & 3.13 & 3.33 & 3.14 & 2.99 & 3.98 \\
\cline { 2 - 11 } & Non-Flipped & 4.01 & 3.75 & 3.86 & 3.94 & 3.63 & 3.43 & 3.23 & 3.67 & 4.10 \\
\hline $60-69$ & Flipped & 3.63 & 3.35 & 3.52 & 3.76 & 3.25 & 3.31 & 3.39 & 3.23 & 3.93 \\
\cline { 2 - 11 } & Non-Flipped & 3.96 & 3.76 & 3.74 & 3.85 & 3.48 & 3.32 & 3.45 & 3.66 & 3.84 \\
\hline \multirow{2}{*}{$70-79$} & Flipped & 3.96 & 3.84 & 3.66 & 3.89 & 3.50 & 3.35 & 3.52 & 3.70 & 3.99 \\
\cline { 2 - 10 } & Non-Flipped & 4.10 & 3.94 & 3.73 & 3.98 & 3.52 & 3.41 & 3.60 & 3.79 & 3.95 \\
\hline \multirow{2}{*}{$80-89$} & Flipped & 4.16 & 4.12 & 3.84 & 4.07 & 3.78 & 3.55 & 3.83 & 3.92 & 4.13 \\
\cline { 2 - 10 } & Non-Flipped & 3.77 & 3.70 & 3.77 & 4.00 & 3.50 & 3.43 & 3.67 & 3.87 & 3.93 \\
\hline $90-100$ & Flipped & 4.33 & 4.30 & 4.15 & 4.29 & 4.02 & 3.78 & 3.79 & 4.22 & 4.56 \\
\cline { 2 - 9 } & Non-Flipped & 3.70 & 3.54 & 3.87 & 4.07 & 3.58 & 3.65 & 3.84 & 3.93 & 3.94 \\
\hline
\end{tabular}

(Note: For convenience, numbers 1, 2, 3, 4, 5, 6, 7, 8, 9 represents different factors like "Student's Collaboration", "Student's Cooperation", “Teacher's Support", “Teacher's Leading", "Classroom Involvement",

"Student's Responsibility", "Task Orientation”, "Equality” and "Teacher's Inno vation” respectively.)

In designing the questionnaire, the students are divided into five different groups based on their 
listening and speaking scores. From Table 4 , it is surprising to be found that mean differences of most environment factors (8 in 9) for students (whose scores are in the interval of 90-100) and of nearly half environment factors for students (whose scores are in the interval of 80-89) are obvious between the flipped classroom and the non-flipped classroom. The higher their scores are, the better feeling of the flipped classroom environment they have, which shows that flipped classroom's influence on good students, especially top students, is significant.

However, for students whose scores are in the low level interval (0-59, and 60-69) the mean differences of most environment factors are negatively obvious between the flipped classroom and the non-flipped classroom. The negative differences are more significant for those students whose scores are under 60. That means flipped classroom has negative effect on poor students' perception of classroom environment of CELS. That is to say, flipped classroom is not helpful for those students whose scores are in the interval of 0-69, which is beyond the researcher's expectation.

For students whose scores are in middle level interval (70-79), the mean differences for most environment factors between the flipped classroom and the non-flipped classroom are negative, but the differences are so slight that they can be neglected when compared to the big differences for other groups of students.

Given that the above differences, the students are divided into two groups in a broader sense, those whose scores are in the high level intervals (80-89, and 90-100) and those whose scores are in the low level intervals (0-59, and 60-69). These two groups are shortly called HLI students and LLI students. The following part will offer more data analyses about students' proficiency difference in their perception of classroom environment between flipped classroom and non-flipped classroom

Difference in Perception of Classroom Environment between HLI Students in FC and HLI Students in NFC

Table 5 Independent Sample Test of Difference between HLI Students in FC and HLI Students in NFC

\begin{tabular}{|l|l|l|l|c|c|c|}
\hline Factors & $\begin{array}{l}\text { Flipped/Non-flip } \\
\text { ped classroom }\end{array}$ & $\mathrm{t}$ & $\mathrm{df}$ & $\begin{array}{c}\text { Sig. } \\
\text { (2-tailed) }\end{array}$ & $\begin{array}{c}\text { Mean } \\
\text { Difference }\end{array}$ & $\begin{array}{l}\text { Std. Error } \\
\text { Difference }\end{array}$ \\
\hline \multirow{3}{*}{$\begin{array}{c}\text { Student's } \\
\text { Collaboration }\end{array}$} & Flipped & 7.016 & 362 & .000 & .39086 & .05571 \\
\cline { 2 - 7 } & Non-Flipped & 6.986 & 348.837 & .000 & .39086 & .05595 \\
\hline \multirow{2}{*}{ Student's Cooperation } & Flipped & 9.710 & 362 & .000 & .58588 & .06034 \\
\cline { 2 - 7 } & Non-Flipped & 9.667 & 348.181 & .000 & .58588 & .06061 \\
\hline \multirow{2}{*}{ Classroom Involvement } & Flipped & 4.905 & 362 & .000 & .26519 & .05407 \\
\cline { 2 - 7 } & Non-Flipped & 4.897 & 357.359 & .000 & .26519 & .05415 \\
\hline \multirow{2}{*}{ Student's Responsibility } & Flipped & 9.710 & 362 & .000 & .58588 & .06034 \\
\cline { 2 - 7 } & Non-Flipped & 9.667 & 348.181 & .000 & .58588 & .06061 \\
\hline
\end{tabular}

Table 5 provides more details about the differences. Between students (whose scores are in the interval of 90-100) in flipped classroom and those in non-flipped classroom, mean differences of Student's Collaboration, Student's Cooperation and Students' Responsibility are obvious. For students whose scores are in the interval of 80-89, mean differences exist among fewer factors and the mean differences are much less compared to those of the former group of students. A tendency is found that the higher the students' scores are, the better feeling of the flipped classroom environment they have. In other words, good students, especially top students, appreciate flipped classroom more. Actually, they are the students who reap more benefits from the experiment.

In Table 5, the $\mathrm{P}$ values of Student's Collaboration, Student's Cooperation, Classroom Involvement, and Student's Responsibility are lower than 0.05 , which also indicates there are significant differences in HLI students' perception of these factors of classroom environment between flipped classroom and non-flipped classroom. 


\section{Difference in Perception of Classroom Environment between LLI Students in FC and LLI Students in NFC}

Table 6 Independent Sample Test of Difference between LLI Students in FC and LLI Students in NFC

\begin{tabular}{|c|c|c|c|c|c|c|}
\hline Factors & $\begin{array}{l}\text { Flipped/Non-flipped } \\
\text { classroom }\end{array}$ & $\mathrm{t}$ & $\mathrm{df}$ & $\begin{array}{c}\text { Sig. } \\
\text { (2-tailed) }\end{array}$ & $\begin{array}{c}\text { Mean } \\
\text { Difference }\end{array}$ & $\begin{array}{c}\text { Std. Error } \\
\text { Difference }\end{array}$ \\
\hline \multirow{2}{*}{$\begin{array}{c}\text { Student's } \\
\text { Collaboration }\end{array}$} & Flipped & -5.436 & 284 & .000 & -.33951 & .06246 \\
\hline \multirow{2}{\text{Classroom}}{} & Non-Flipped & -5.468 & 283.985 & .000 & -.33951 & .06209 \\
\cline { 2 - 7 } Involvement & Flipped & -4.163 & 284 & .000 & -.25019 & .06009 \\
\hline Equality & Non-Flipped & -4.191 & 283.984 & .000 & -.25019 & .05969 \\
\cline { 2 - 7 } & Flipped & -6.586 & 284 & .000 & -.45579 & .06920 \\
\cline { 2 - 7 } & Non-Flipped & -6.633 & 283.951 & .000 & -.45579 & .06872 \\
\hline
\end{tabular}

Table 6 offers a clearer picture about the differences. Between students (whose scores are in the interval of (60-69) in flipped classroom and those in non-flipped classroom, mean differences of 3 environment factors like Student's Collaboration, Classroom Involvement, and Equality are evident, but the differences are negative. As for students whose scores are below 60, negative mean differences exist in more factors. Among them, mean differences for Student's Cooperation and Equality are much more compared to those of the students whose scores are in the interval of 60-69. So a tendency can be found that flipped classroom is not welcome by the poor students, especially those students whose English proficiency is very limited. These students think the flipped classroom environment is worse than that of the normal class. Under such circumstances, their performances are even worse. We can see that the experiment doesn't benefit them as we expected.

As can be seen from Table 6, the P values of Student's Collaboration, Classroom Involvement and Equality are all lower than 0.05, which also indicates there are significant differences in LLI students' perception of these factors of classroom environment between flipped classroom and non-flipped classroom.

\section{Summary.}

From what have been discussed above, we can conclude that there exists proficiency difference in perception of CELS classroom environment between students in flipped classroom and those in non-flipped classroom. Students in high score level may feel easy in the flipped classroom, and they can finish the after-class and in-classroom tasks well. Flipped classroom provides them more chances to communicate with other students as well as the teacher, and they can develop their creativity and self-organization ability. But the influence of the flipped classroom on the students in low score level is negative. They are not good at learning by themselves after class, and their input is not enough. When they come back to classroom, the classroom activities are hard for them. They can't finish tasks assigned by the teacher on time, so the flipped classroom is a burden for them.

Data from the interview indicate that not all students like the flipped classroom, especially for students with poor English. For good students, flipped classroom has given them more chances to learn by themselves and demonstrate themselves, which enhances their self-learning abilities and creativity. They become the master of learning. But for poor students, flipped classroom still has to be improved in some aspects. Teachers should make adjustments while taking these students' language proficiency, interest, anxiety, etc. into full consideration.

\section{Findings and Suggestions}

Flipped classroom pedagogy brings about many advantages. However, it doesn't mean flipped classroom exerts the same effect on different classes or on students of different proficiency levels.

Students with good command of English benefit more from flipped classroom pedagogy. They have good control of their self-learning and are better-prepared for class activities, so they cooperate and interact with other students as well as with the teacher more actively. Correspondingly, their perceptions of classroom environment are better. On the contrary, students with poor English feel 
more of the negative effect of flipped classroom. These students meet more difficulties in their self-learning. They are not well-prepared for the class tasks so that they are less confident and motivated in taking part in class activities. It is not surprising to be found that they don't think highly of the flipped classroom environment. Similar tendency also goes for the top classes and bottom classes.

Based on the findings, suggestions for teachers employing flipped classroom pedagogy are put forward as follows:

1. Teachers who adopt flipped classroom pedagogy should take class differences into consideration. In good classes or top classes, students have better command of English and are more capable of self-learning, so tasks assigned to them, both in-class and after-class, can be more diverse and challenging. This will help them more in improving their language proficiency as well as their internalizing of the learned knowledge. For poor classes, especially the bottom classes, teachers should make some adjustments in assigning the tasks. The tasks can be less challenging and more helpful to arouse the students' interest and to build their confidence. In addition, in class, teachers can allot more time for interpreting the difficult points and answering questions from the students. By helping to remove the students' learning barriers, a more cooperative and interactive learning environment will be obtained.

2. In flipped classroom, teachers should also consider the individual differences. For good students, especially top students, teachers can offer them more challenging tasks. For students with poor English proficiency, the teacher should better offer them more support and encouragement. More understanding for them and more communication with them are also necessary. Only by getting rid of their anxiety, worry and pressure can they take more active part in the classroom activities, which ultimately helps to improve the classroom environment effectively.

\section{Conclusion}

The results of this study indicate the influence and significance of flipped classroom teaching on Listening and Speaking classroom environment and affirm the necessity of the graded teaching of College English. However, there are some limitations. For example, the samples are limited, and the experiment teaching time is not long enough, which all have certain impacts on the universality of research results. Future research can expand the experimental samples to explore the relationship between environment factors and the learners' self-efficacy, the relationship between classroom environment and students' learning motivation and so on. As for flipped classroom, substantial technical supports (mobile apps) make it possible to have large-scale implementation of this teaching method. In addition, further research can shift to the feasibility of flipped classroom teaching in other courses such as Integrated College English, English Writing, and English Translating, etc.

\section{Acknowledgements}

Teaching research project of Hubei Provincial Department of Education: "College English Reading, Writing and Translating Classroom Environment Research" (No. 2012230)

\section{References}

[1]. Alvarez, B. Flipping the classroom: Homework in class, lessons at home. [J]. Education Digest: Essential Readings Condensed For Quick Review, 2011, No.8, p18-21.

[2]. Baker, J. W. The "classroom flip": Using web course management tools to become the guide on the side [A]. In Chambers, J. A.(ed). Selected Papers from the 11th International Conference on College Teaching and Learning [C]. Jacksonville, FL: Florida Community College at Jacksonville, 2000, p9-17. 
[3]. Strayer, J. The Effects of the Classroom Flip on the Learning Environment: A Comparison of Learning Activity in A Traditional Classroom and Flip Classroom that Used an Intelligent Tutoring System [D]. OH: The Ohio State University, 2007.

[4]. X.L.Ma and G.Q.Zhao and T.Wu: An Empirical Study on the Influence of Flipped Classroom Model on Information Technology Course Teaching [J]. Journal of Distance Education, 2013, No.1, p79-85. (In Chinese)

[5]. Y.Shen and Y.D. Sheng: Study of the Flipped College English Classroom Based on Community of Inquiry [J]. Foreign Language World, 2015, No.4, p81-89. (In Chinese)

[6]. C.L.Zhao and J.J.Xu: Research on Learning Adaptability and Learning Ability Development in Flipped Classroom-Based on the View of Learning Activities Design [J]. China Educational Technology, 2015(341):92-98. (In Chinese)

[7]. Johnson, L. and Adams Becker, S. (2014). NMC horizon report: 2014 higher education edition. Austin, Texas: The New Media Consortium.

[8]. Retrieved from http://www.nmc.org/pdf/2014-nmc-horizon-report-he-EN.pdf.

[9]. C.L.Fan and Q. Dong: International and Comparative Education, 2005, No.8, p62-66. (In Chinese)

[10]. Y.M.Sun: Foreign Language Teaching and Research(bimonthly), 2010, No.6,p.438-444. (In Chinese) 